\title{
Long non-coding RNAs: novel regulators of cellular physiology and function
}

\author{
James A. Oo $o^{1,2} \cdot$ Ralf P. Brandes ${ }^{1,2} \cdot$ Matthias S. Leisegang ${ }^{1,2}$ (1) \\ Received: 12 October 2021 / Revised: 29 October 2021 / Accepted: 3 November 2021 / Published online: 18 November 2021 \\ (c) The Author(s) 2021
}

\begin{abstract}
Long non-coding RNAs were once considered as "junk" RNA produced by aberrant DNA transcription. They are now understood to play central roles in diverse cellular processes from proliferation and migration to differentiation, senescence and DNA damage control. LncRNAs are classed as transcripts longer than 200 nucleotides that do not encode a peptide. They are relevant to many physiological and pathophysiological processes through their control of fundamental molecular functions. This review summarises the recent progress in lncRNA research and highlights the far-reaching physiological relevance of lncRNAs. The main areas of lncRNA research encompassing their characterisation, classification and mechanisms of action will be discussed. In particular, the regulation of gene expression and chromatin landscape through lncRNA control of proteins, DNA and other RNAs will be introduced. This will be exemplified with a selected number of lncRNAs that have been described in numerous physiological contexts and that should be largely representative of the tens-of-thousands of mammalian IncRNAs. To some extent, these lncRNAs have inspired the current thinking on the central dogmas of epigenetics, RNA and DNA mechanisms.
\end{abstract}

Keywords Long non-coding RNA $\cdot$ Physiology $\cdot$ Pathophysiology $\cdot$ ncRNA

\section{LncRNA characteristics and classification}

The advancement of next generation sequencing and bioinformatic techniques in the last 20 years has led to the detection of genome-wide transcriptional events within non-coding regions and the subsequent discovery of thousands of long non-coding RNAs (lncRNAs). Countless studies have already revealed that lncRNAs are relevant for many physiological and pathophysiological processes (Fig. 1A-C) and that these can often be connected to the respective lncRNA molecular mechanisms of action.

Only a small fraction of the human transcriptome is translated into proteins since the majority of RNA transcripts are non-coding. These non-coding RNAs can be further divided into small non-coding RNAs, such as miRNAs, tRNAs, snoRNAs and snRNAs, and long non-coding RNAs

Matthias S. Leisegang

Leisegang@vrc.uni-frankfurt.de

1 Institute for Cardiovascular Physiology, Goethe University, Theodor-Stern-Kai 7, 60590 Frankfurt, Germany

2 German Centre of Cardiovascular Research (DZHK), Partner Site RheinMain, Frankfurt, Germany
(lncRNAs) which are longer than 200 nucleotides (Fig. 2A) [61]. Current estimates place the number of human IncRNAs at around 100,000 according to the NONCODE (v6) database [78]. Despite their lack of coding potential, IncRNAs share multiple features with mRNAs including (1) RNA polymerase II-mediated transcription regulated by common epigenetic marks such as tri-methylation of lysine 4 of histone 3 (H3K4me3); (2) a 7-methyl guanosine (m7G) 5'-Cap and Poly-A tail; and (3) splicing of multi-exonic transcripts, albeit less efficiently for lncRNAs than for mRNAs [61]. IncRNAs can be found anywhere in the cell but with the majority being localised to the nucleus; potentially a consequence of inefficient splicing events [56]. In contrast to mRNAs, many lncRNAs are relatively lowly expressed, less well conserved evolutionarily and highly cell type- or tissuespecific [61]. This difference is supported by studies demonstrating that lncRNA promoters contain fewer transcription factor (TF) binding motifs and TF binding events. Additionally, it is believed that the lower abundance of lncRNA transcripts cannot be explained by RNA degradation alone [56]. LncRNAs also form secondary and tertiary structures and contain functional RNA elements and nuclear localisation sequences, which are assumed to be important primarily 
Figure 1 Publications about lncRNAs are existing in many different physiological areas. A-C Number of pubmed entries since 2008 for lncRNA and the individual tissue (A), cell type (B) or disease (C). PubMed searches were performed with the following terms: ("LncRNA" AND "search term") OR ("Long non-coding RNA" AND "search term") OR ("long non coding RNA" AND "search term"), as of date 5th October 2021.

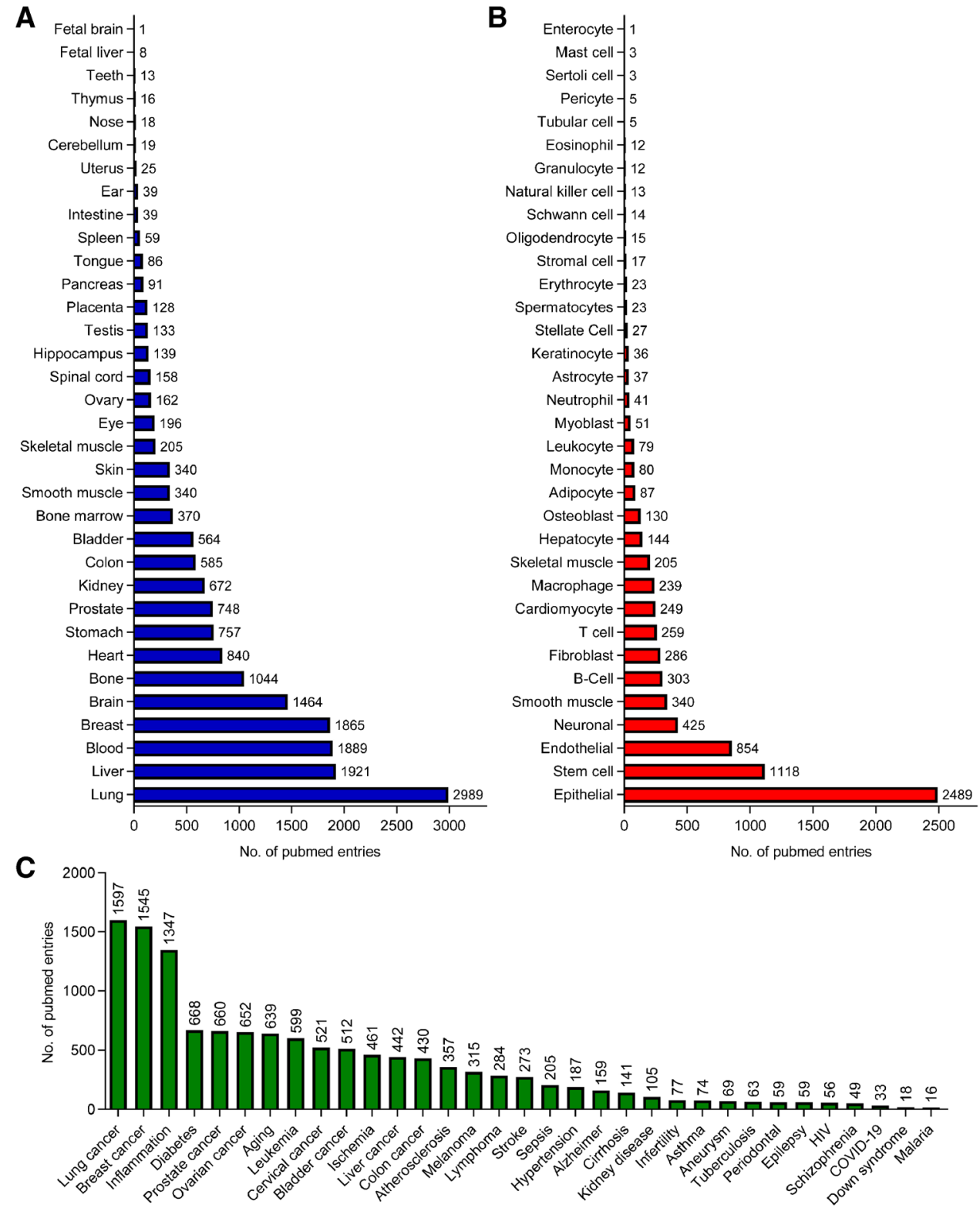

for gene regulation [56, 67]. These regulatory motifs and higher order structures enable an exceedingly diverse range of lncRNA functions.

An official and appropriate classification that encompasses all lncRNAs does not yet exist [46]. One proposed method of lncRNA classification is based on their genomic position relative to other genes, such as protein-coding genes (Fig. 2B): (1) Divergent and antisense lncRNAs either overlap or are in close proximity to a sense gene and are localised on the opposite DNA strand; (2) intronic lncRNAs are transcribed from the intron of a sense or antisense gene; and (3) intergenic lncRNA genes which do not overlap other genes [46]. Each of these genomic arrangements are able to produce molecular and physiologically relevant lncRNAs. Other means of classification can be based on lncRNA modes of action and regulation, which include but are not limited to target gene regulation (by cis- or trans-acting lncRNAs, Fig. 2C) [46], molecular role (e.g. competitive endogenous RNAs [63], enhancer RNAs [32], architectural RNAs [8]), their transcriptional regulation (e.g. stress-induced promoter-associated antisense lncRNAs [20], damage-induced lncRNAs [50]) or their physiological relevance (e.g. AngioLncRs [74]). More recently, it has been suggested that the process of transcription itself could have an important function independent of the IncRNA transcript produced from that transcriptional activity. For example, the locus could be part of a 3D nuclear construct permissive to chromatin environment and gene regulation at the neighbouring locus [1]. Similarly, some lncRNAs may not be entirely non-coding and, despite their low coding potential, may give rise to 
Figure 2 Research outlines and lncRNA characteristics. A

LncRNA transcripts are defined as non-coding RNAs longer than 200nt apparently lacking protein coding potential. Typically, the majority of lncRNAs are mRNA-like RNAs harbouring a 5'Cap and a polyA tail. B Genomic location of lncRNA genes. C LncRNAs can act in cis to regulate the immediate locus from which the lncRNA was transcribed, in trans to function elsewhere in the cell or trans-secreted. D For some lncRNA genes, functions on their gene itself, their transcript or peptide are known increasing the layer of complexity for their mode of operations.

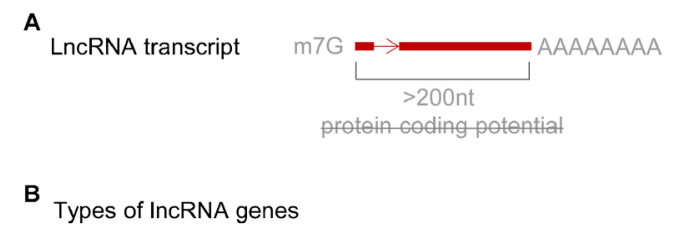

C Functions of IncRNAs
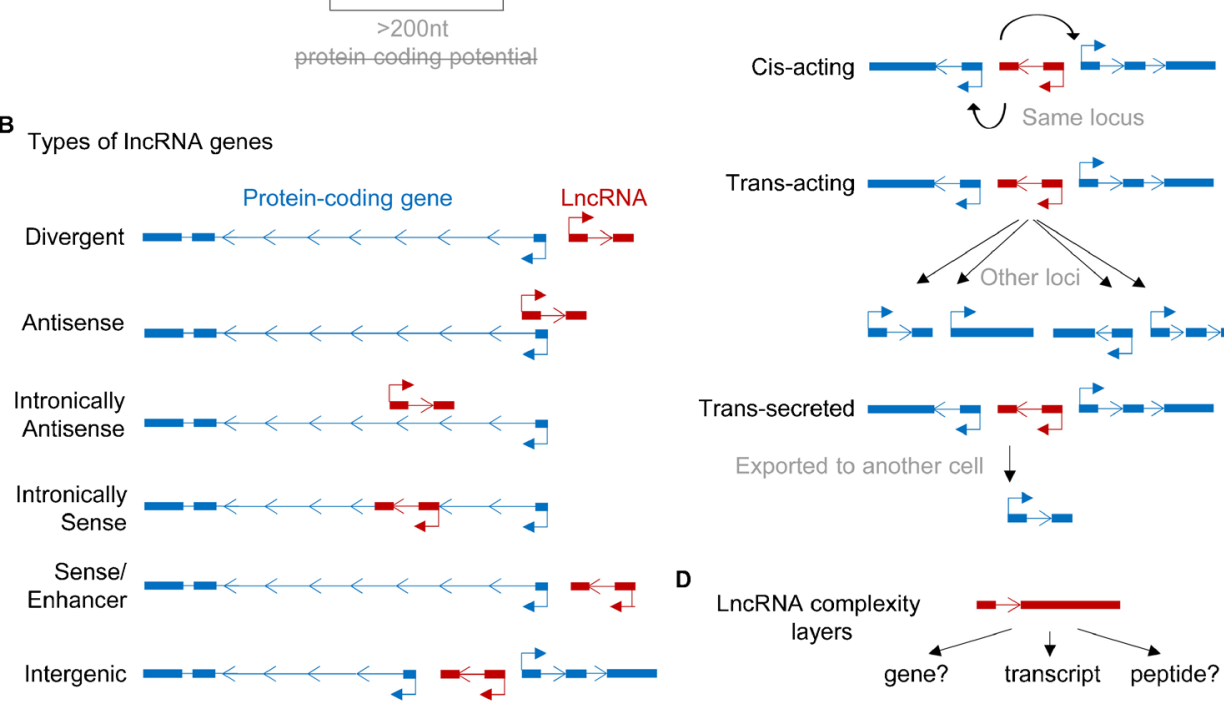

small functional peptides (so-called micropeptides) while retaining an independent RNA function (Fig. 2D) [61]. This highlights that our understanding of the lncRNA landscape is subject to change and that an appropriate method of classification encompassing all lncRNAs remains a challenge.

\section{The diverse functions of IncRNAs}

LncRNAs usually enact their functions by interacting with proteins, metabolites, DNA or even other RNAs. Additionally, important regulatory elements may be embedded within the gene body of IncRNA genes where transcriptional activity can influence genome structure, chromatin accessibility and neighbouring gene activity [1]. IncRNAs themselves are highly modifiable with many different "post-transcriptional" modifications reported so far, such as N6-methyladenosine (m6A), pseudouridine ( $\Psi), 5$-methylcytosine (m5C) and N1-methyladenosine (m1 A) [14, 15, 40, 49, 60, 77], where m6A for example can influence RNA structure to alter protein interactions [42] or lncRNA functions [43]. LncRNAs have been shown to be involved in many cellular processes, mainly in transcriptional regulation, post-transcriptional regulation (e.g. splicing), cell organellar and structural organisation and genome integrity [61]. The mechanisms of gene expression regulation by lncRNAs are particularly diverse since lncRNAs bind other molecules in abundance. This allows for multiple mechanisms whereby lncRNAs permit or inhibit the interactions between these molecules; for example the recruitment or decoying of chromatin remodelling complexes, proteins mediating histone modifications, transcription factor binding to gene regulatory regions or the interaction of RNA with DNA that leads to R-Loop or triplex formation [61]. This not only impacts on transcription but also on genome stability. LncRNAs frequently serve as scaffolds as in the case of several forms of nuclear condensates, which are membraneless RNA-protein compartments [61]. Post-transcriptional functions of lncRNAs include the interference of mRNA splicing, turnover, decay and translation. LncRNAs can also affect cellular function through interaction with other ncRNAs, such as miRNAs. This so-called competitive endogenous RNA function often leads to the protection of miRNA-targets [61]. Finally, the homeostasis of organelles such as exosomes and mitochondria has even been linked to lncRNAs [61]. Taken together, these diverse means of regulation and the mechanisms through which lncRNAs subsequently enact their functions allow for the fine-tuning and regulation of cellular processes that have consequences for many physiological processes.

\section{LncRNAs are physiologically relevant}

Despite the fact that most lncRNAs are so far uncharacterised, there already exists an exhaustive list of lncRNAs that have been investigated across almost all physiological systems. Bioinformatic databases, as reviewed in [53], or RNA analysis tools, such as the RNA atlas [45] (R2: Genomics Analysis and Visualization Platform (http://r2. amc.nl)), provide an abundance of lncRNA data which can be exploited by researchers working in many different areas of physiology.

Here, we will present examples of highly physiologically relevant lncRNAs and describe their mechanisms of action (Fig. 3). It should be stressed that we cannot cover all physiological processes and systems in one review and 
Figure 3 lncRNAs in various physiological systems and processes. LncRNAs have been shown to be fundamental in almost all physiological systems and processes. Example lncRNAs are provided for the major physiological systems and for a select number of general physiological processes to highlight the ubiquitous nature of lncRNAs.

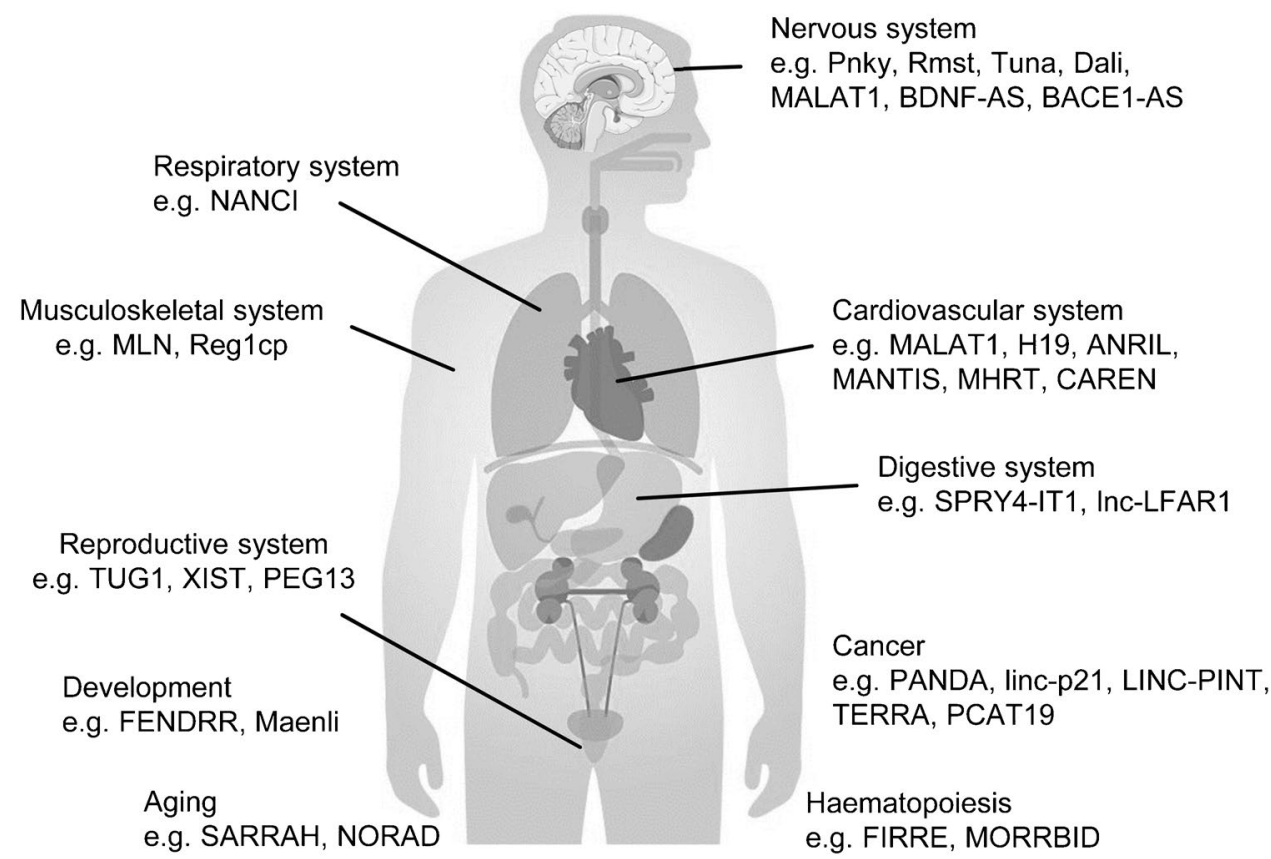

instead select a handful of lncRNAs that should be largely representative of the functions of this class of molecules. Additionally, many of these lncRNAs are involved in pathophysiological processes that have, for the most part, been historically characterised from a protein perspective. Finally, this review should also exemplify the strong influence that single lncRNAs can have on disease outcome: knowledge that can hopefully provide a platform for future basic and therapeutic RNA research.

\section{Loss of expression studies revealed that IncRNAs play critical roles in vivo}

As early as 2013, a study with 18 lncRNA knockout mouse strains revealed that IncRNAs are important for viability and are involved in the development of lungs and the cerebral cortex. Peri- and postnatal lethal phenotypes were observed in lncRNA Fendrr (FOXF1 Adjacent Non-Coding Developmental Regulatory RNA), Peril, and Mdgt mutant strains and growth defects were reported for linc-Brnlb and linc-Pint. $\mathrm{Fendrr}^{-/-}$neonates displayed defects in multiple organs. Linc-Brn $1 b^{-/-}$mutants showed distinct abnormalities in the generation of upper layer II-IV neurons in the neocortex [58]. Lai et al. analysed 20 different lncRNA knockouts with a variety of phenotypes in mice, ranging from perinatal lethality to defects associated with premature aging and morphological and functional abnormalities in the lungs, skeleton and muscle [35]. An increased expression with age of the IncRNA Lincpint was observed in parallel with a reduction in body weight, probably due to reduced total body fat and lower femur bone mineral density, and the development of lordokyphosis. Knockout of Fendrr led to an abnormal lung morphology, Hotair knockout mice displayed a homeotic transformation in the 4th caudal vertebra and Hottip knockout showed hindlimb malformations [35]. In a largescale cell culture analysis, as part of the FANTOM6 project, Ramilowski et al. knocked down 194 lncRNAs with at least two antisense oligonucleotides in human dermal fibroblasts and quantified cellular growth, morphological changes and transcriptomic responses with Capped Analysis of Gene Expression (CAGE) to measure the molecular phenotype. The authors observed that around $30 \%$ of the lncRNAs were associated with cell growth and morphological changes [54].

\section{X-chromosome inactivation, the first paradigm for a function of a IncRNA}

$X$-inactive specific transcript (XIST) was one of the earliest described lncRNAs and, as such, studies on this lncRNA have provided an invaluable framework for research in the lncRNA field. Xist is responsible for X-chromosome inactivation; a process which achieves dosage compensation of the sex chromosomal genes between females and males. Both $\mathrm{X}$ chromosomes, the $\mathrm{Xa}$ (active) and $\mathrm{Xi}$ (inactive) chromosomes, contain the XIST gene, with the $\mathrm{Xi}$ gene initiating $\mathrm{X}$-chromosomal inactivation during early development. Xist is transcribed and spreads in cis across the X-chromosome to coat $\mathrm{Xi}$, but not $\mathrm{Xa}$. The lncRNA triggers gene silencing by recruiting chromatin modifying factors including the polycomb-repressive complex 2 (PRC2), which results in a huge structural reorganization of the X-chromosome [17, 44]. 
lncRNA loci can be functionally highly complex as demonstrated in a study by Lewandowski et al. The authors identified that the widely expressed and highly conserved Tugl lncRNA is important for male fertility. Tug 1 -knockout mice were sterile with underlying defects in spermatogenesis as indicated by a low sperm count and abnormal sperm morphology. Molecular characterisation revealed that Tugl, however, functions beyond its role as a lncRNA: the locus acts as a cis-DNA repressor regulating neighbouring gene expression, whereas the lncRNA itself has a trans-regulatory function. Furthermore, the overexpression of an evolutionarily conserved open reading frame of Tugl encoded a protein identified to be important for mitochondrial membrane potential [39].

Mice lacking the $3^{\prime}$ half of paternally expressed gene, Peg13, which is part of a complex of imprinted genes on chromosome 15 in mice, showed distinct behavioural differences: they prefer to associate with their own sex after losing interest in the opposite sex. They also develop a higher level of anxiety, lowered activity and curiosity, and a deficiency in pup retrieval behaviour. The authors analysed whole-brain RNA of 16-week-old Peg13-deficient mice and revealed that expression of genes involved in the serotonergic system, formation of glutamatergic synapses, olfactory processing, and estrogen signalling and several others of the imprinted genes on chromosome 15 were changed. It was concluded that Pegl3 is part of a regulatory network that governs the female-male differentiation of the brain, as well as the neurobiology of social interactions [31].

\section{Developmental processes are dependent on IncRNAs}

LncRNAs are also known to be central in developmental processes where their altered regulation often promotes disease. Grote et al. identified the lateral mesoderm-specific lncRNA Fendrr which regulates the development of the heart and body wall of developing mouse embryos [21]. In a similar manner as many other lncRNAs, Fendrr binds chromatin-associated protein complexes, specifically PRC2, and recruits it to genes where PRC2 deposits Histone3 Lysine 27 trimethylation (H3K27me3) marks, leading to transcriptional repression. Concomitantly, Fendrr represses the Trithorax group/mixed lineage leukaemia complex (TrxG/MLL) at the same gene targets to prevent H3K4me3 deposition, normally associated with gene activation. This work highlights the cell-type specificity yet crucial roles of IncRNAs, where their perturbation can have drastic consequences on fundamental physiological processes such as organ development.

MAENLI (master activator of engrailed-1 in the limb) is a IncRNA whose transcriptional activity is important for the deposition of active histone marks (Fig. 4A). Its deletion causes a severe human Mendelian disease [2]. Allou et al. identified homozygous $27-63 \mathrm{~kb}$ deletions located $300 \mathrm{~kb}$ upstream of the engrailed-1 gene (ENI) on human chromosome 2 in patients with a severe, recessively inherited congenital limb malformation featuring mesomelic shortening, syndactyly and ventral nails (dorsal dimelia). These deletions led to the loss of EnI expression in the limbs of mice and a similar phenotypic outcome. Interestingly, they identified an unknown limb-expressed lncRNA within the deleted region, which they termed Maenli and which is part of an Enl topologically associated domain, the central locus control element during embryonic limb development. The Maenli locus itself is essential to drive limb-specific EnI activation in cis simply through its transcriptional activity. Mechanistically, Maenli transcription led to the deposition of H3K4me3 epigenetic marks on the EnI and Maenli loci and the surrounding regulatory landscape. A similar effect on limb malformation was also seen after depletion of IncRNA Hottip in mice [35] and chicks [68], where Wang et al. showed that active chromatin of the $5^{\prime}$ HOXA cluster was controlled by Hottip RNA [68].

\section{Haematopoiesis and the immune system are controlled by IncRNAs}

LncRNA FIRRE is a trans-acting lncRNA that regulates lymphopoiesis. Mice with Firre mutations have been shown to exhibit cell-specific lymphocyte phenotypes displayed by a reduction in the abundance of CD4 and CD8 T cells. Moreover, upon exposure to lipopolysaccharide, mice overexpressing Firre exhibited increased levels of the proinflammatory cytokines TNF $\alpha$, IL12-p40, and MIP-2 and impaired survival [38].

Morrbid is a cis-acting lncRNA tightly controlling the lifespan of neutrophils, eosinophils and classical monocytes in response to pro-survival cytokines in mice. Mechanistically, the IncRNA promotes the enrichment of PRC2 and $\mathrm{H} 3 \mathrm{~K} 27 \mathrm{me} 3$ at the promoter of its neighbouring gene, the pro-apoptotic gene Bcl2ll1 (BIM), which leads to repression of transcription. The lncRNA was found to be upregulated in individuals with hypereosinophilic syndrome, which is characterised by a persistently elevated eosinophil count [34].

\section{LncRNAs associated with aging}

Aging is one of the main risk factors for numerous diseases. Trembinski et al. identified the conserved lncRNA Sarrah (SCOT1-antisense RNA regulated during aging in the heart), also known as OXCT1-AS1, as downregulated in aged mice and infarcted hearts [64]. Loss of the lncRNA impaired contractile force development in human engineered heart tissue. Sarrah was responsible for cardiomyocyte survival as its silencing led to apoptosis while 
A

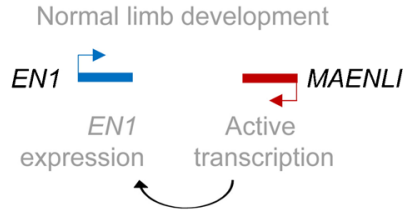

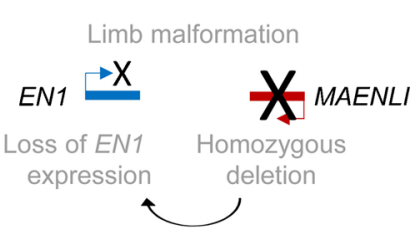

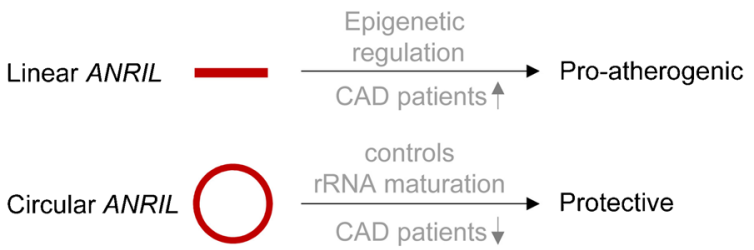

C

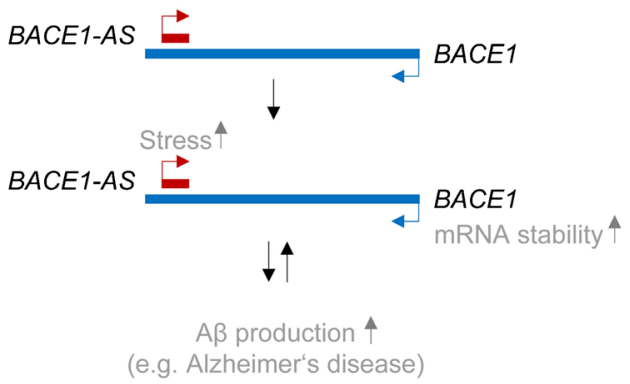

D

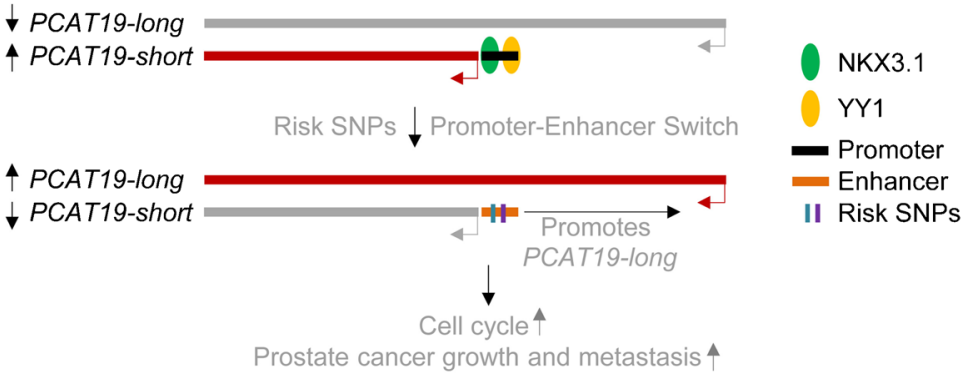

Figure 4 MAENLI, ANRIL, BACE1-AS1 and PCAT19 as examples of physiologically relevant lncRNA mechanisms. A For normal limb development, transcriptional activity of the MAENLI locus itself is required to activate EN1 expression. Homozygous loss or deletion of the MAENLI locus abolish its transcriptional activity leading to the loss of EN1 expression and limb malformation. B Linear ANRIL expression is increased in patients with coronary artery disease (CAD) patients and has pro-atherogenic functions through epigenetic rearrangements leading to altered expression of genes involved in atherosclerosis. Circular ANRIL, whose expression is decreased in CAD patients, is important for controlling rRNA maturation to protect from over-proliferation of vascular cells. C LncRNA BACE1-AS increases

its overexpression in mice improved their recovery from acute myocardial infarction. Mechanistically, the authors suggested that SARRAH forms RNA-DNA triplexes at gene promoters, which were downregulated after $S A R$ $R A H$ silencing. An induction of NRF2 and the binding of CRIP2 and p300 facilitated transcriptional activation of SARRAH target genes.

Another lncRNA involved in aging is NORAD, which protects the genome by reducing the activity of PUMILIO proteins. NORAD depletion leads to overactivation of PUMILIO proteins with augmented repression of a program of target mRNAs that includes key regulators of mitosis, DNA repair, and DNA replication. Dysregulation of these genes could result in genomic instability in Noraddeficient cells reflected by faster aging in animals. Such a relationship is putatively seen since PUMILIO levels increase with age while those of NORAD decrease [48]. The investigation of the physiological function of lncRNA Norad by Kopp et al. revealed that Norad depletion led to a degenerative phenotype characterised by increased alopecia, gray fur, kyphosis and aging-associated pathologies within the central nervous system, which is the consequence of genomic instability and mitochondrial dysfunction, explained by PUMILIO2 overexpression [33]. the mRNA stability of $B A C E 1$, resulting in an increased protein level of the $\beta$-secretase, which produces amyloid beta 1-42. This in turn activates $B A C E 1-A S$ expression in a positive feedback loop. D PCAT19 has two isoforms, a long and a short isoform. The short form is dominating and promoted by binding of the transcription factors NKX3.1 and YY1 to the short isoform promoter. Two risk SNPs for prostate cancer are located within the promoter of PCAT19short, preventing NKX3.1 and YY1 from binding. The SNP-affected PCAT19-short promoter switches to an enhancer, promoting the expression of PCAT19-long. PCAT19-long activates transcription of genes involved in cell cycle and the growth and metastasis of prostate cancer cells.

\section{LncRNAs and their function in individual organ systems}

\section{The cardiovascular system}

Cardiovascular disease encompasses a diverse range of pathologies that make it the number one cause of death worldwide [70]. It is therefore unsurprising that many lncRNAs have been studied in the context of cardiovascular physiology and pathophysiology.

The lncRNA MALATl is one of the few very highly expressed lncRNAs. Initially identified as a cancer biomarker [30], MALAT1 has diverse roles in multiple different cancer types [62]. In the cardiovascular system, it was shown to be associated with atherosclerotic lesion formation in mice and with human atherosclerotic disease [10]. Reduced levels of Malatl had pro-atherosclerotic effects, which resulted from an increased accumulation of haematopoietic cells at the murine carotid artery vessel wall [10]. In failing hearts of mice, pigs and humans, expression of the lncRNA $H 19$ was reduced and an $H 19$ vector-based, cardiomyocyte-directed gene therapy was able to attenuate heart failure [66]. 
Multiple studies have been performed on the Chr9p21 locus, where numerous CAD risk SNPs accumulated within the gene encoding the IncRNA ANRIL (antisense noncoding RNA in the INK4 locus). ANRIL is an example of a lncRNA locus transcribing multiple isoforms, two of which are highly physiologically relevant: a linear lncRNA and a circular RNA with opposing functions (Fig. 4B). Linear ANRIL has pro-atherogenic effects involving mechanisms with Alu elements important for epigenetic gene regulation; however, the circular ANRIL isoform has putative protective functions which are mediated by inhibition of circular ANRIL's interaction partner Pescadillo Ribosomal Biogenesis Factor 1 (PES1), a member of the PeBoW (Pes1, Bop1 and WDR12) complex. Inhibition of PeBoW leads to defects in rRNA maturation, increased nucleolar stress and activation of $\mathrm{p} 53$, which inhibits cell proliferation and increases apoptosis, whereas linear ANRIL confers overproliferation [26].

MANTIS is an example of a nuclear scaffolding lncRNA having a critical function in endothelial cells. Its depletion leads to a loss of the ability of endothelial cells to align in the direction of flow. Moreover, MANTIS is required to promote angiogenesis, limit inflammatory gene expression and maintain angiogenic capacity [36, 37]. Consequently, knockdown of MANTIS increased the adhesion of monocytes to endothelial cells in an ICAM-1-dependent manner. Statin therapy induced MANTIS in vitro and in patients with carotid artery disease. MANTIS also maintained the pleiotropic responses of endothelial cells to atorvastatin. Central to these effects is the interaction of MANTIS with the SWI/SNF chromatin remodelling complex member, BRG1. MANTIS guides BRG1 to its different effector genes, resulting in activation of pro-angiogenic gene expression and inhibition of inflammatory gene expression in endothelial cells [37].

LncRNA Mhrt is also connected to the chromatin remodeller BRG1. The IncRNA functions to limit cardiac hypertrophy by binding to and inhibiting the helicase domain of BRG1 to create a transcriptional feedback loop [22]. The inhibition of DNA-binding proteins is a common lncRNA mechanism of action that has profound effects on pathophysiological outcome.

The IncRNA Caren (Cardiomyocyte-enriched transcript) is a prime example of a cytoplasm-enriched lncRNA with a pivotal role in the development of a highly complex disease. It protects against the development of heart failure in pressure-overloaded hearts by inhibiting Hint1. Hint1 is a tumour suppressor that activates the ATM kinase and the DNA damage response (DDR), a process that is prominent in cardiomyocytes of patients with heart failure. Caren's protective effects are related to the inhibition of Hint1-mediated mitochondrial dysfunction and DDR signalling through ATM. At least in mice, the overexpression of Caren alone is sufficient to prevent heart failure [57].

\section{The nervous system}

lncRNA studies in the central nervous system have revealed a striking specificity of IncRNA expression in nervous tissue. Neurogenesis, the differentiation of neural stem cells (NSC) to neurons is a highly complex but wellorchestrated process that involves multiple physiological, molecular and genetic pathways. It is becoming evident that lncRNAs provide an additional layer of molecular control and that this is particularly true in neurogenesis and the complex differentiation of the brain.

Pnky (previously called lnc-pou $3 f 2$ ) is an evolutionarily conserved and neural-specific lncRNA involved in embryonic and postnatal neurogenesis. Pnky interacts with the RNA splicing regulator PTBP1 to mediate the expression and alternative splicing of transcripts important for limiting neural differentiation and neurogenesis [55]. PTBP1 has the ability to drive brain tumour growth and invasiveness [18], exemplifying the importance of PTBP1 inhibition by Pnky. Other prominent lncRNAs such as RMST (rhabdomyosarcoma 2-associated transcript) [52], TUNA (Tcll Upstream Neuron-Associated lincRNA) [41] and Dali (DNMT1-Associated Long Intergenic) [6] also function in neurogenesis by physically interacting with proteins important for the regulation of neural gene expression. IncRNAs have also been shown to function in other central nervous processes such as synaptogenesis. Expression of the Brain-Derived Neurotrophic Factor (BDNF), which is essential for neuronal differentiation, maturation and growth, is inhibited by the BDNF antisense lncRNA, BDNF-AS [51]. Malat1, mentioned above for its function in tumours and the cardiovascular system, also controls the expression of genes involved in synaptogenesis and synapse function [4]. Many of the lncRNAs mentioned here are highly cell-type specific. On the other hand, MALATI is ubiquitously expressed and has been shown to perform fundamental tasks in many cell types.

Given their roles in neuronal differentiation and development, it stands to reason that lncRNAs are involved in diseases of the nervous system, like neurodegeneration. For example, a central protein in the development of Alzheimer's disease (AD), $\beta$-secretase (BACE1), produces the $\beta$ amyloid plaques that are a hallmark of $\mathrm{AD}$ pathophysiology [11]. Interestingly, BACE1 expression is regulated to some degree by its antisense transcript, $B A C E 1-A S$ (Fig. 4C). Disease-promoting factors such as amyloid-beta 1-42 upregulate $B A C E 1-A S$ which promotes BACE1 expression and BACE1 mRNA stability to produce more amyloid beta 1-42 in a positive feedback loop [16]. This opens the possibility for RNA therapeutics targeting $B A C E 1-A S$ and therefore BACE1 expression, which itself has already been the focus of intense AD therapeutic research [9]. 


\section{The respiratory system}

As mentioned above already, lncRNAs are required for tissue and organ development, and this is also true for lung tissue. The lncRNA NANCI (Nkx2.1-associated non-coding intergenic RNA) associates with and promotes the expression of the $\mathrm{Nkx} 2.1$ transcription factor, which is crucial for pulmonary development and homeostasis. Loss of NANCI itself is not sufficient to limit development, since it is normally inhibited by Nkx2.1 in a negative feedback loop; however, mutations which impact both NANCI and Nkx2.1 lead to severe lung degeneration [25].

The lncRNA TYKRIL (tyrosine kinase receptor-inducing lncRNA) was found to be strongly upregulated in the pulmonary arterial pericytes and smooth muscle cells (SMC) of patients with idiopathic pulmonary arterial hypertension (IPAH) [75]. TYKRIL was shown to promote proliferation under the hypoxic conditions that are characteristic of IPAH. Interestingly, knockdown of TYKRIL was found to increase p53 levels which consequently repressed platelet-derived growth factor receptor $\beta$ (PDGFR $\beta$ ), a known driver of SMC proliferation. As such, TYKRIL has a profound influence on the development of PAH. Many lncRNAs have been shown to interact with and regulate p53 [7]; however, TYKRIL is the first lncRNA demonstrated to mediate the p53/PDGFR $\beta$ axis specifically. This exemplifies the fact that individual lncRNAs are capable of mediating common RNA-binding proteins in a precise and distinct manner.

One study demonstrated that the lung tissue from smokers with chronic obstructive pulmonary disorder (COPD) expressed 120 upregulated and 43 downregulated lncRNAs compared to smokers without COPD [12]. Similarly, smokers without COPD expressed 87 upregulated and 244 downregulated lncRNAs compared to non-smokers. This study nicely illustrates that whole networks of lncRNAs can be differentially expressed in a cell-type- and condition-specific manner.

\section{The digestive system}

The intestinal barrier includes the chemical mucosal and physical epithelial layers that allow for selective absorption of nutrients, ions and water into the bloodstream. Barrier integrity is upheld by the tight junction proteins which are tightly regulated through multiple signalling pathways; dysregulation of which predisposes to inflammatory bowel diseases and metabolic disorders. IncRNAs also play a role in the context of intestinal barrier integrity. For example, depletion of the lncRNA SPRY4-IT1 disrupted barrier integrity by reducing the stability of mRNAs encoding tight junction proteins claudin-1, claudin-3, occludin and JAM-1 [71]. Similarly, the lncRNA H19, heavily studied in the cardiovascular and cancer fields, is also involved in barrier integrity.
H19 acts as a precursor for microRNA 675 (miR-675) which represses the expression and reduces the stability of tight junction proteins $\mathrm{ZO}-1$ and E-cadherin through its interaction with the RNA-binding protein HuR [79].

Zhang et al. identified the multi-functional lnc-LFAR1 (liver fibrosis-associated lncRNA1) that promotes liver fibrosis, a disease characterised by extracellular matrix component accumulation in the liver leading to hepatic dysfunction. Silencing of lnc-LFAR 1 impaired hepatic stellate cells activation, reduced TGF $\beta$-induced hepatocytes apoptosis and attenuated the $\mathrm{CCl}_{4}$ - and bile duct ligation-induced liver fibrosis in mice. The authors revealed that Lnc-LFAR1 has multiple functions organising Smad2/3 binding, phosphorylation and induction to promote liver fibrosis leading to the activation of the TGF $\beta$ and Notch pathways [76].

\section{Musculoskeletal system}

By definition, lncRNAs should lack protein-coding potential. However, as in the case for the lncRNA Tugl mentioned above, a peptide coded by the Myoregulin (MLN) IncRNA was shown to be important for skeletal muscle performance. MLN KO mice had improved skeletal muscle exercise performance and muscle $\mathrm{Ca}^{2+}$ handling. The conserved micropeptide of the IncRNA, which encodes a transmembrane alpha helix with strong structural resemblance to phospholamban and sarcolipin-direct interactors with SERCA in the sarcoplasmatic reticulum membrane-co-localises with SERCA and regulates $\mathrm{Ca}^{2+}$ handling by inhibiting SERCA pump activity [3].

As already mentioned for $A N R I L$, physiologically important SNPs are not restricted to protein-coding genes. Yang et al. identified a novel mutation on chromosome 2 (rs3819316 C > T) in the lncRNA Reglcp that is associated with elevated bone mass. Mutant Reglcp increased the formation of the CD $31^{\text {hi }} \mathrm{Emcn}^{\text {hi }}$ endothelium in the bone marrow to stimulate angiogenesis during osteogenesis. They identified Krüppel-like factor 3 (KLF3) as a protein interaction partner of mutant, but not wild-type Reglcp in human microvascular ECs, and showed that binding of KLF3 to its downstream target JUNB is reduced by mutant Reglcp. Endothelial-specific Klf3 knockout mice also had increased CD31 ${ }^{\text {hi }} \mathrm{Emcn}^{\text {hi }}$ endothelium and bone formation [73].

\section{Cancer development and progression}

Given the expression of lncRNAs across all tissues and their involvement in fundamental cellular processes, it is unsurprising that lncRNAs have been linked to cancer development and progression. Cancer is a highly complex disease whose hallmarks include, among others, immune evasion, genome instability, angiogenesis and sustained proliferation 
[23, 24]. Databases such as Lnc2Cancer [19] and Cancer LncRNA Census [65] list lncRNAs already identified to be involved in cancer.

The lncRNAs PANDA, linc-p21 and LINC-PINT are lncRNAs that function to alter transcription factor activity and binding $[13,29,47]$. One of the main members of the coordinated response to genomic instability and mutations arising from DNA damage is the p53 tumour suppressor protein. Hung et al. sought to discover lncRNAs that impact p53-induced cell-cycle arrest [29] and found that the lncRNA termed PANDA (P21-associated ncRNA DNA damage activated) is upregulated by p53. Fibroblasts with PANDA knockdown displayed increased DNA damage, and a higher sensitivity to DNA damage-induced apoptosis. Interestingly, PANDA interacted with the p53-downstream transcription factor nuclear transcription factor $Y$ subunit alpha (NF-YA), which bound more to its target genes after PANDA knockdown. These data suggested that $P A N D A$, in response to DNA damage, represses NF-YA target gene binding and thereby blocks apoptosis to promote cell survival. Huarte et al. identified a p53-repressor and pro-apoptotic lncRNA termed lincRNA-p21 [28]. lincRNA-p21 functions as a mediator of other p53 gene targets. Independent knockdowns of p53 or lincRNA-p21 revealed an overlap of 930 differentially regulated genes, $80 \%$ of which were returned to normal expression levels after a double knockdown of p53 and lincRNA- $p 21$. Mechanistically, lincRNA-p21 recruited and enabled the localisation of hnRNP-K as a p53-dependent repressor that drives the apoptotic response to DNA damage. Cancer cells often develop the ability to depart the primary tumour and invade other tissues and organs to form metastases. The p53-regulated lncRNA LINC-PINT was shown to act as a tumour suppressor, owing to its ability to reduce the invasive and migratory potential of cancer cells [47]. LINCPINT overexpression was sufficient to downregulate many genes that drive invasion such as Early Growth Response 1 (EGR1), Phospholipase D1 (PLD1), SERPINE1, Fibronectin (FN1) and Integrin alpha 3 (ITGA3), with the upstream regulator identified as $\beta$-catenin. The mechanistic function of LINC-PINT is to recruit PRC2 to these invasion-related genes to repress their transcription.

LncRNA TERRA is recruited to telomeres where it stabilises protein-telomere interactions [5]. Telomere shortening determines the replicative potential of cells [72]. Telomeres are repetitive sequences capping the ends of chromosomes; these become shorter with each cell division, eventually losing the ability to protect the chromosome ends and inducing replicative senescence. Cancer cells often have higher levels of telomerase which can lengthen the telomeres and thereby circumvent telomere-induced replicative senescence, important to maintain cancer cell replicative immortality [59]. A highly conserved lncRNA termed TERRA (telomeric repeatcontaining RNA) is transcribed from telomeres and acts in trans as indicated by its ability to regulate telomeres on other chromosomes in addition to that from which it was transcribed. TERRA is recruited to telomeres and stabilises the interaction of proteins with telomeres. As well as regulating telomerase directly, TERRA can also form RNA-DNA hybrid structures known as R-loops at telomeres to induce homologous recombination and delay senescence. This has been proposed as the mechanism by which telomeres are preserved in the $10 \%$ of cancers that do not have elevated telomerase levels [5].

PCAT19 (prostate cancer associated transcript 19) is another example of a lncRNA whose SNPs have been linked to pathophysiological effects (Fig. 4D). The gene encoding IncRNA PCAT19 contains a single-nucleotide polymorphism (SNP) that differentially regulates the expression of a short and long isoform of PCAT19 [27]. The presence of the SNP variant decreases the binding of transcription factors NKX3.1 and YY1 to the PCAT19-short promoter that switches to an enhancer and upregulates the PCAT19-long isoform. This long isoform of PCAT19 binds hnRNPAB to activate the transcription of genes involved in cell cycle and the growth and metastasis of prostate cancer tumours. Sustained proliferation is one of the central characteristics of cancer cells.

\section{Conclusion and outlook}

The remarkable progress in the field of lncRNA research has provided evidence that lncRNAs are highly relevant for physiology, development and behaviour. As such, IncRNAs are implicated in a number of diseases, often by fine-tuning gene regulation. Due to their extensive number of features, functions and expression patterns, there is no doubt that lncRNAs offer a great potential and perspective for future interventions such as tissue regeneration and personalised medicine. LncRNA research could lead to innovations that engineer synthetically active IncRNAs for RNA-based therapeutics.

As is the case for protein-coding genes or other ncRNAs, IncRNAs are more than just biomarkers; they are potentially highly specific therapeutic targets [69]. Antisense oligonucleotides targeting natural antisense transcripts (NATs) are an interesting option and showed promising preclinical results. These so-called antagoNATs were used for gene reactivation in the central nervous system and upregulated brain-derived neurotrophic factor and the healthy allele of sodium voltage-gated channel alpha subunit 1 [69]. Not only does this underline the fundamental roles that lncRNAs can play, but it also highlights their potential druggability in many disease scenarios.

Only a relatively small fraction of lncRNAs has been studied so far with the physiological roles of the majority of 
lncRNAs remaining unknown. Current research is just beginning to examine whether IncRNA genomic loci are functionally independent of the RNA transcript and whether small peptide-coding RNAs add an additional layer of regulation to the system. This raises important questions surrounding the multiple functions of IncRNAs, e.g. on genomic locus-, transcript- and peptide-levels. Many lncRNAs are speciesand tissue-specific, indicating that the role of transcriptional activities around the lncRNA loci, the chromatin architecture and regulatory sequence elements within or closely attached to IncRNA gene bodies could be important. Additionally, the structural features of lncRNAs need to be considered. Future studies will also reveal the physiological importance of lncRNA-containing phase-separated condensates, RNA modifications and certain lncRNA isoforms at the single-cell level. The classification of this large group of ncRNAs will also be simplified once a more complete picture of lncRNA biology exists. This could be based on their functionality, processing, structural features and interaction with other RNAs, DNA or proteins. Here, lncRNA databases should take centre stage.

There is no doubt that the progress of lncRNA research will lead to a better understanding of physiological and pathophysiological processes, their fine-tuning and epigenetic control, which can then be used interdisciplinarily to advance therapies and to improve disease outcome.

\section{Glossary}

Alu elements Short stretches of repetitive DNA that act as transposable elements (mobile genetic elements that can move around the genome). Alu elements are located across the genome and are believed to be functionally relevant, particularly in the generation of new genes in the process of evolution.

cis-acting lncRNAs lncRNAs that regulate gene activity at the same locus from which the lncRNA is transcribed.

Functional elements Regions of DNA that have a known regulatory function such as promoter regions where transcription factors bind to initiate gene transcription; and enhancers where molecules bind to potentiate the activation of an associated gene.

Histone modifications Covalent post-translational modifications of the histone proteins that comprise the nucleosome (the basic functional unit of chromatin). Histone modifications include acetylation, methylation, phosphorylation, sumoylation and ubiquitylation to name a few and can regulate the transcriptional state of a gene.

m7G 5' cap A methylated guanine nucleotide with a triphosphate linkage on the 5' end of primary RNA transcripts. This 7-methylguanylate $(\mathrm{m} 7 \mathrm{G})$ functions in nuclear export, intron excision, inhibition of degradation and translation in the case of mRNAs.

Oligonucleotide Short stretches of DNA or RNA that have a wide range of applications in molecular biology research.

Poly-A tail Stretch of RNA consisting exclusively of adenine bases. Important for RNA stability, termination of transcription, nuclear export and translation.

R-loop Three-stranded DNA:RNA structure consisting of two antiparallel DNA strands and an RNA strand. R-loops are involved in gene regulation and genome stability.

SNP SNPs (single-nucleotide polymorphisms) are substitutions of a single nucleotide in the genome. The majority of SNPs have no functional consequence but some can influence gene regulation and ultimately disease development, depending on their precise location.

Splicing The process whereby introns are removed from a primary RNA transcript and the exons joined to form the mature RNA transcript.

trans-acting lncRNA lncRNAs that leave their site of transcription to function elsewhere in the cell.

Triplex Three-stranded oligonucleotide structures of DNA:DNA:RNA in which the RNA occupies the major groove of the DNA and binds through Hoogsteen pairing with the purines of the Watson-Crick basepairs.

Acknowledgements We apologise to all colleagues whose work was not described here due to strict length limitations.

Author contribution JAO, RPB and MSL conceived the idea for the article, performed literature search, wrote the article and critically revised the work. MSL drafted the work.

Funding Open Access funding enabled and organized by Projekt DEAL. This work was supported by the Goethe University Frankfurt am Main, the German Centre for Cardiovascular Research (DZHK, PostDoc Startup Grant, 81X3200107) and the DFG Transregio TRR267 (TPA04\&TPA06).

\section{Declarations}

Competing interests The authors declare no competing interests.

Open Access This article is licensed under a Creative Commons Attribution 4.0 International License, which permits use, sharing, adaptation, distribution and reproduction in any medium or format, as long as you give appropriate credit to the original author(s) and the source, provide a link to the Creative Commons licence, and indicate if changes were made. The images or other third party material in this article are included in the article's Creative Commons licence, unless indicated otherwise in a credit line to the material. If material is not included in the article's Creative Commons licence and your intended use is not permitted by statutory regulation or exceeds the permitted use, you will need to obtain permission directly from the copyright holder. To view a copy of this licence, visit http://creativecommons.org/licenses/by/4.0/. 


\section{References}

1. Ali T, Grote P (2020) Beyond the RNA-dependent function of LncRNA genes. Elife 9. https://doi.org/10.7554/eLife.60583

2. L Allou S Balzano A Magg M Quinodoz B Royer-Bertrand R Schöpflin W-L Chan CE Speck-Martins DR Carvalho L Farage CM Lourenço R Albuquerque S Rajagopal S Nampoothiri B Campos-Xavier C Chiesa F Niel-Bütschi L Wittler B Timmermann M Spielmann MI Robson A Ringel V Heinrich G Cova G Andrey CA Prada-Medina R Pescini-Gobert S Unger L Bonafé P Grote C Rivolta S Mundlos A Superti-Furga 2021 Non-coding deletions identify Maenli lncRNA as a limb-specific En1 regulator Nature 5929398 https://doi.org/10.1038/s41586-021-03208-9

3. DM Anderson KM Anderson C-L Chang CA Makarewich BR Nelson JR McAnally P Kasaragod JM Shelton J Liou R BasselDuby EN Olson 2015 A micropeptide encoded by a putative long noncoding RNA regulates muscle performance Cell 160595606 https://doi.org/10.1016/j.cell.2015.01.009

4. D Bernard KV Prasanth V Tripathi S Colasse T Nakamura Z Xuan MQ Zhang F Sedel L Jourdren F Coulpier A Triller DL Spector A Bessis 2010 A long nuclear-retained non-coding RNA regulates synaptogenesis by modulating gene expression EMBO J 293082 3093 https://doi.org/10.1038/emboj.2010.199

5. Bettin N, Oss Pegorar C, Cusanelli E (2019) The emerging roles of TERRA in telomere maintenance and genome stability. Cells 8. https://doi.org/10.3390/cells8030246

6. V Chalei SN Sansom L Kong S Lee JF Montiel KW Vance CP Ponting 2014 The long non-coding RNA Dali is an epigenetic regulator of neural differentiation Elife 3 e04530 https://doi.org/ 10.7554/eLife.04530

7. R Chaudhary A Lal 2017 Long noncoding RNAs in the p53 network Wiley Interdiscip Rev RNA 8 e1410 https://doi.org/10.1002/ wrna. 1410

8. T Chujo T Yamazaki T Hirose 2016 Architectural RNAs (arcRNAs): A class of long noncoding RNAs that function as the scaffold of nuclear bodies Biochim Biophys Acta 1859139146 https://doi.org/10.1016/j.bbagrm.2015.05.007

9. Cole SL, Vassar R (2007) The basic biology of BACE1: a key therapeutic target for Alzheimer's disease. CG 8:509-530. https:// doi.org/10.2174/138920207783769512

10. S Cremer KM Michalik A Fischer L Pfisterer N Jaé C Winter RA Boon M Muhly-Reinholz D John S Uchida C Weber W Poller S Günther T Braun DY Li L Maegdefessel L Perisic Matic U Hedin O Soehnlein A Zeiher S Dimmeler 2019 Hematopoietic deficiency of the long noncoding RNA MALAT1 promotes atherosclerosis and plaque inflammation Circulation 13913201334 https://doi. org/10.1161/CIRCULATIONAHA.117.029015

11. B Das R Yan 2017 Role of BACE1 in Alzheimer's synaptic function Transl Neurodegener 623 https://doi.org/10.1186/ s40035-017-0093-5

12. D Devadoss $C$ Long RJ Langley M Manevski M Nair MA Campos G Borchert I Rahman HS Chand 2019 Long noncoding transcriptome in chronic obstructive pulmonary disease Am J Respir Cell Mol Biol 61678688 https://doi.org/10.1165/rcmb.2019-0184TR

13. N Dimitrova JR Zamudio RM Jong D Soukup R Resnick K Sarma AJ Ward A Raj JT Lee PA Sharp T Jacks 2014 LincRNA-p21 activates p21 in cis to promote Polycomb target gene expression and to enforce the G1/S checkpoint Mol Cell 54777790 https:// doi.org/10.1016/j.molcel.2014.04.025

14. D Dominissini S Moshitch-Moshkovitz S Schwartz M SalmonDivon L Ungar S Osenberg K Cesarkas J Jacob-Hirsch N Amariglio M Kupiec R Sorek G Rechavi 2012 Topology of the human and mouse m6A RNA methylomes revealed by m6A-seq Nature 485201206 https://doi.org/10.1038/nature11112
15. D Dominissini S Nachtergaele S Moshitch-Moshkovitz E Peer N Kol MS Ben-Haim Q Dai A Segni Di M Salmon-Divon WC Clark G Zheng T Pan O Solomon E Eyal V Hershkovitz D Han LC Doré N Amariglio G Rechavi C He 2016 The dynamic N(1)-methyladenosine methylome in eukaryotic messenger RNA Nature 530 441446 https://doi.org/10.1038/nature16998

16. MA Faghihi F Modarresi AM Khalil DE Wood BG Sahagan TE Morgan CE Finch G St Laurent PJ Kenny C Wahlestedt 2008 Expression of a noncoding RNA is elevated in Alzheimer's disease and drives rapid feed-forward regulation of beta-secretase Nat Med 14723730 https://doi.org/10.1038/nm1784

17. A Fatica I Bozzoni 2014 Long non-coding RNAs: new players in cell differentiation and development Nat Rev Genet 15721 https://doi.org/10.1038/nrg3606

18. R Ferrarese GR Harsh AK Yadav E Bug D Maticzka W Reichardt SM Dombrowski TE Miller AP Masilamani F Dai H Kim M Hadler DM Scholtens ILY Yu J Beck V Srinivasasainagendra F Costa N Baxan D Pfeifer D Elverfeldt von R Backofen A Weyerbrock CW Duarte X He M Prinz JP Chandler H Vogel A Chakravarti JN Rich MS Carro M Bredel 2014 Lineage-specific splicing of a brain-enriched alternative exon promotes glioblastoma progression J Clin Invest 12428612876 https://doi.org/ 10.1172/JCI68836

19. Y Gao P Wang Y Wang X Ma H Zhi D Zhou X Li Y Fang W Shen Y Xu S Shang L Wang L Wang S Ning X Li 2019 Lnc2Cancer v2.0: updated database of experimentally supported long non-coding RNAs in human cancers Nucleic Acids Res 47 D1028 D1033 https://doi.org/10.1093/nar/gky1096

20. A Giannakakis J Zhang P Jenjaroenpun S Nama N Zainolabidin MY Aau AA Yarmishyn C Vaz AV Ivshina OV Grinchuk M Voorhoeve LA Vardy P Sampath VA Kuznetsov IV Kurochkin E Guccione 2015 Contrasting expression patterns of coding and noncoding parts of the human genome upon oxidative stress Sci Rep 59737 https://doi.org/10.1038/srep09737

21. P Grote L Wittler D Hendrix F Koch S Währisch A Beisaw K Macura G Bläss M Kellis M Werber BG Herrmann 2013 The tissue-specific lncRNA Fendrr is an essential regulator of heart and body wall development in the mouse Dev Cell 24206214 https://doi.org/10.1016/j.devcel.2012.12.012

22. P Han W Li C-H Lin J Yang C Shang ST Nuernberg KK Jin W Xu C-Y Lin C-J Lin Y Xiong H Chien B Zhou E Ashley D Bernstein P-S Chen H-SV Chen T Quertermous C-P Chang 2014 A long noncoding RNA protects the heart from pathological hypertrophy Nature 514102106 https://doi.org/10.1038/natur e13596

23. D Hanahan RA Weinberg 2000 The hallmarks of cancer Cell 100 5770 https://doi.org/10.1016/S0092-8674(00)81683-9

24. D Hanahan RA Weinberg 2011 Hallmarks of cancer: the next generation Cell 144646674 https://doi.org/10.1016/j.cell.2011. 02.013

25. MJ Herriges DJ Tischfield Z Cui MP Morley Y Han A Babu S Li M Lu I Cendan BA Garcia SA Anderson EE Morrisey 2017 The NANCI-Nkx2.1 gene duplex buffers Nkx2.1 expression to maintain lung development and homeostasis Genes Dev 31889 $903 \mathrm{https} / / /$ doi.org/10.1101/gad.298018.117

26. LM Holdt D Teupser 2018 Long noncoding RNA ANRIL: Lncing genetic variation at the chromosome 9p21 locus to molecular mechanisms of atherosclerosis Front Cardiovasc Med 5145 https://doi.org/10.3389/fcvm.2018.00145

27. JT Hua M Ahmed H Guo Y Zhang S Chen F Soares J Lu S Zhou M Wang H Li NB Larson SK McDonnell PS Patel Y Liang CQ Yao T Kwast van der M Lupien FY Feng A Zoubeidi M-S Tsao SN Thibodeau PC Boutros HH He 2018 Risk SNP-mediated promoter-enhancer switching drives prostate cancer through lncRNA PCAT19 Cell 174564 575.e18 https://doi.org/10.1016/j.cell.2018. 06.014 
28. M Huarte M Guttman D Feldser M Garber MJ Koziol D Kenzelmann-Broz AM Khalil O Zuk I Amit M Rabani LD Attardi A Regev ES Lander T Jacks JL Rinn 2010 A large intergenic noncoding RNA induced by p53 mediates global gene repression in the p53 response Cell 142409419 https://doi.org/10.1016/j. cell.2010.06.040

29. T Hung $Y$ Wang MF Lin AK Koegel Y Kotake GD Grant HM Horlings N Shah C Umbricht P Wang Y Wang B Kong A Langerød A-L Børresen-Dale SK Kim M Vijver van de S Sukumar ML Whitfield M Kellis Y Xiong DJ Wong HY Chang 2011 Extensive and coordinated transcription of noncoding RNAs within cell-cycle promoters Nat Genet 43621629 https://doi. org/10.1038/ng.848

30. P Ji S Diederichs W Wang S Böing R Metzger PM Schneider $\mathrm{N}$ Tidow B Brandt H Buerger E Bulk M Thomas WE Berdel H Serve C Müller-Tidow 2003 MALAT-1, a novel noncoding RNA, and thymosin beta4 predict metastasis and survival in early-stage non-small cell lung cancer Oncogene 2280318041 https://doi.org/10.1038/sj.onc.1206928

31. Keshavarz M, Tautz D (2021) The imprinted lncRNA Peg13 regulates sexual preference and the sex-specific brain transcriptome in mice. Proc Natl Acad Sci U S A 118. https://doi.org/10. 1073/pnas.2022172118

32. Kim T-K, Hemberg M, Gray JM (2015) Enhancer RNAs: a class of long noncoding RNAs synthesized at enhancers. Cold Spring Harb Perspect Biol 7. https://doi.org/10.1101/cshperspect.a0186 22

33. Kopp F, Elguindy MM, Yalvac ME, Zhang H, Chen B, Gillett FA, Lee S, Sivakumar S, Yu H, Xie Y, Mishra P, Sahenk Z, Mendell JT (2019) PUMILIO hyperactivity drives premature aging of Norad-deficient mice. Elife 8. https://doi.org/10.7554/ eLife.42650

34. JJ Kotzin SP Spencer SJ McCright DBU Kumar MA Collet WK Mowel EN Elliott A Uyar MA Makiya MC Dunagin CCD Harman AT Virtue S Zhu W Bailis J Stein C Hughes A Raj EJ Wherry LA Goff AD Klion JL Rinn A Williams RA Flavell J Henao-Mejia 2016 The long non-coding RNA Morrbid regulates Bim and shortlived myeloid cell lifespan Nature 537239243 https://doi.org/10. 1038/nature19346

35. K-MV Lai G Gong A Atanasio J Rojas J Quispe J Posca D White M Huang D Fedorova C Grant L Miloscio G Droguett WT Poueymirou W Auerbach GD Yancopoulos D Frendewey J Rinn DM Valenzuela 2015 Diverse phenotypes and specific transcription patterns in twenty mouse lines with ablated LincRNAs PLoS ONE 10 e0125522 https://doi.org/10.1371/journal.pone.0125522

36. MS Leisegang C Fork I Josipovic FM Richter J Preussner J Hu MJ Miller J Epah P Hofmann S Günther F Moll C Valasarajan J Heidler Y Ponomareva TM Freiman L Maegdefessel KH Plate M Mittelbronn S Uchida C Künne K Stellos RT Schermuly N Weissmann K Devraj I Wittig RA Boon S Dimmeler SS Pullamsetti M Looso FJ Miller RP Brandes 2017 Long noncoding RNA MANTIS facilitates endothelial angiogenic function Circulation 13665 79 https://doi.org/10.1161/CIRCULATIONAHA.116.026991

37. MS Leisegang S-I Bibli S Günther B Pflüger-Müller JA Oo C Höper S Seredinski M Yekelchyk T Schmitz-Rixen C Schürmann J Hu M Looso F Sigala RA Boon I Fleming RP Brandes 2019 Pleiotropic effects of laminar flow and statins depend on the Krüppel-like factor-induced lncRNA MANTIS Eur Heart J 40 25232533 https://doi.org/10.1093/eurheartj/ehz393

38. JP Lewandowski JC Lee T Hwang H Sunwoo JM Goldstein AF Groff NP Chang W Mallard A Williams J Henao-Meija RA Flavell JT Lee C Gerhardinger AJ Wagers JL Rinn 2019 The Firre locus produces a trans-acting RNA molecule that functions in hematopoiesis Nat Commun 105137 https://doi.org/10.1038/ s41467-019-12970-4
39. JP Lewandowski G Dumbović AR Watson T Hwang E JacobsPalmer N Chang C Much KM Turner C Kirby ND Rubinstein AF Groff SC Liapis C Gerhardinger A Bester PP Pandolfi JG Clohessy HE Hoekstra M Sauvageau JL Rinn 2020 The Tug1 lncRNA locus is essential for male fertility Genome Biol 21237 https://doi.org/10.1186/s13059-020-02081-5

40. X Li X Xiong M Zhang K Wang Y Chen J Zhou Y Mao J Lv D Yi X-W Chen C Wang S-B Qian C Yi 2017 Base-resolution mapping reveals distinct $\mathrm{m} 1 \mathrm{~A}$ methylome in nuclear- and mitochondrialencoded transcripts Mol Cell 68993 1005.e9 https://doi.org/10. 1016/j.molcel.2017.10.019

41. N Lin K-Y Chang Z Li K Gates ZA Rana J Dang D Zhang T Han C-S Yang TJ Cunningham SR Head G Duester PDS Dong TM Rana 2014 An evolutionarily conserved long noncoding RNA TUNA controls pluripotency and neural lineage commitment Mol Cell 5310051019 https://doi.org/10.1016/j.molcel.2014.01.021

42. N Liu Q Dai G Zheng C He M Parisien T Pan 2015 N(6)-methyladenosine-dependent RNA structural switches regulate RNAprotein interactions Nature 518560564 https://doi.org/10.1038/ nature 14234

43. H Liu Y Xu B Yao T Sui L Lai Z Li 2020 A novel N6-methyladenosine (m6A)-dependent fate decision for the lncRNA THOR Cell Death Dis 11613 https://doi.org/10.1038/s41419-020-02833-y

44. A Loda E Heard 2019 Xist RNA in action: past, present, and future PLoS Genet 15 e1008333 https://doi.org/10.1371/journal. pgen. 1008333

45. Lorenzi L, Chiu H-S, Avila Cobos F, Gross S, Volders P-J, Cannoodt R, Nuytens J, Vanderheyden K, Anckaert J, Lefever S, Tay AP, Bony EJ de, Trypsteen W, Gysens F, Vromman M, Goovaerts T, Hansen TB, Kuersten S, Nijs N, Taghon T, Vermaelen K, Bracke KR, Saeys Y, Meyer T de, Deshpande NP, Anande G, Chen T-W, Wilkins MR, Unnikrishnan A, Preter K de, Kjems J, Koster J, Schroth GP, Vandesompele J, Sumazin P, Mestdagh P (2021) The RNA Atlas expands the catalog of human non-coding RNAs. Nat Biotechnol. https://doi.org/10. 1038/s41587-021-00936-1

46. L Ma VB Bajic Z Zhang 2013 On the classification of long noncoding RNAs RNA Biol 10925933 https://doi.org/10.4161/rna. 24604

47. O Marín-Béjar AM Mas J González D Martinez A Athie X Morales M Galduroz I Raimondi E Grossi S Guo A Rouzaut I Ulitsky M Huarte 2017 The human lncRNA LINC-PINT inhibits tumor cell invasion through a highly conserved sequence element Genome Biol 18202 https://doi.org/10.1186/s13059-017-1331-y

48. Marques FC, Ulitsky I (2019) Aging well with Norad. Elife 8. https://doi.org/10.7554/eLife.45974

49. KD Meyer Y Saletore P Zumbo O Elemento CE Mason SR Jaffrey 2012 Comprehensive analysis of mRNA methylation reveals enrichment in 3' UTRs and near stop codons Cell 14916351646 https://doi.org/10.1016/j.cell.2012.05.003

50. F Michelini S Pitchiaya V Vitelli S Sharma U Gioia F Pessina M Cabrini Y Wang I Capozzo F Iannelli V Matti S Francia GV Shivashankar NG Walter FF d'Adda Di 2017 Damage-induced lncRNAs control the DNA damage response through interaction with DDRNAs at individual double-strand breaks Nat Cell Biol 1914001411 https://doi.org/10.1038/ncb3643

51. F Modarresi MA Faghihi MA Lopez-Toledano RP Fatemi M Magistri SP Brothers MP Brug van der C Wahlestedt 2012 Inhibition of natural antisense transcripts in vivo results in gene-specific transcriptional upregulation Nat Biotechnol 30453459 https:// doi.org/10.1038/nbt.2158

52. S-Y Ng GK Bogu BS Soh LW Stanton 2013 The long noncoding RNA RMST interacts with SOX2 to regulate neurogenesis Mol Cell 51349359 https://doi.org/10.1016/j.molcel.2013.07.017 
53. Pinkney HR, Wright BM, Diermeier SD (2020) The lncRNA toolkit: databases and in silico tools for lncRNA analysis. Noncoding RNA 6. https://doi.org/10.3390/ncrna6040049

54. JA Ramilowski CW Yip S Agrawal J-C Chang Y Ciani IV Kulakovskiy M Mendez JLC Ooi JF Ouyang N Parkinson A Petri L Roos J Severin K Yasuzawa I Abugessaisa A Akalin IV Antonov E Arner A Bonetti H Bono B Borsari F Brombacher CJF Cameron CV Cannistraci R Cardenas M Cardon H Chang J Dostie L Ducoli A Favorov A Fort D Garrido N Gil J Gimenez R Guler L Handoko J Harshbarger A Hasegawa Y Hasegawa K Hashimoto N Hayatsu P Heutink T Hirose EL Imada M Itoh B Kaczkowski A Kanhere E Kawabata H Kawaji T Kawashima ST Kelly M Kojima N Kondo H Koseki T Kouno A Kratz M Kurowska-Stolarska ATJ Kwon J Leek A Lennartsson M Lizio F López-Redondo J Luginbühl S Maeda VJ Makeev L Marchionni YA Medvedeva A Minoda F Müller M Muñoz-Aguirre M Murata H Nishiyori KR Nitta S Noguchi Y Noro R Nurtdinov Y Okazaki V Orlando D Paquette CJC Parr OJL Rackham P Rizzu DF Sánchez Martinez A Sandelin P Sanjana CAM Semple Y Shibayama DM Sivaraman T Suzuki SC Szumowski M Tagami MS Taylor C Terao M Thodberg S Thongjuea V Tripathi I Ulitsky R Verardo IE Vorontsov C Yamamoto RS Young JK Baillie ARR Forrest R Guigó MM Hoffman CC Hon T Kasukawa S Kauppinen J Kere B Lenhard C Schneider H Suzuki K Yagi MJL Hoon de JW Shin P Carninci 2020 Functional annotation of human long noncoding RNAs via molecular phenotyping Genome Res 3010601072 https://doi.org/10.1101/ gr.254219.119

55. AD Ramos RE Andersen SJ Liu TJ Nowakowski SJ Hong C Gertz RD Salinas H Zarabi AR Kriegstein DA Lim 2015 The long noncoding RNA Pnky regulates neuronal differentiation of embryonic and postnatal neural stem cells Cell Stem Cell 16439447 https:// doi.org/10.1016/j.stem.2015.02.007

56. JL Rinn HY Chang 2020 Long noncoding RNAs: molecular modalities to organismal functions Annu Rev Biochem 89283 308 https://doi.org/10.1146/annurev-biochem-062917-012708

57. M Sato T Kadomatsu K Miyata JS Warren Z Tian S Zhu H Horiguchi A Makaju A Bakhtina J Morinaga T Sugizaki K Hirashima K Yoshinobu M Imasaka M Araki Y Komohara T Wakayama S Nakagawa S Franklin K Node K Araki Y Oike 2021 The lncRNA Caren antagonizes heart failure by inactivating DNA damage response and activating mitochondrial biogenesis Nat Commun 122529 https://doi.org/10.1038/s41467-021-22735-7

58. M Sauvageau LA Goff S Lodato B Bonev AF Groff C Gerhardinger DB Sanchez-Gomez E Hacisuleyman E Li M Spence SC Liapis W Mallard M Morse MR Swerdel MF D'Ecclessis JC Moore V Lai G Gong GD Yancopoulos D Frendewey M Kellis RP Hart DM Valenzuela P Arlotta JL Rinn 2013 Multiple knockout mouse models reveal lincRNAs are required for life and brain development Elife 2 e01749 https://doi.org/10.7554/eLife.01749

59. JW Shay Y Zou E Hiyama WE Wright 2001 Telomerase and cancer Hum Mol Genet 10677685 https://doi.org/10.1093/hmg/10.7. 677

60. JE Squires HR Patel M Nousch T Sibbritt DT Humphreys BJ Parker CM Suter T Preiss 2012 Widespread occurrence of 5-methylcytosine in human coding and non-coding RNA Nucleic Acids Res 4050235033 https://doi.org/10.1093/nar/gks144

61. L Statello C-J Guo L-L Chen M Huarte 2021 Gene regulation by long non-coding RNAs and its biological functions Nat Rev Mol Cell Biol 2296118 https://doi.org/10.1038/s41580-020-00315-9

62. Sun Y, Ma L (2019) New Insights into Long non-coding RNA MALAT1 in cancer and metastasis. Cancers (Basel) 11. https:// doi.org/10.3390/cancers11020216

63. Y Tay J Rinn PP Pandolfi 2014 The multilayered complexity of ceRNA crosstalk and competition Nature 505344352 https://doi. org/10.1038/nature12986
64. DJ Trembinski DI Bink K Theodorou J Sommer A Fischer A Bergen van C-C Kuo IG Costa C Schürmann MS Leisegang RP Brandes T Alekseeva B Brill A Wietelmann CN Johnson A Spring-Connell M Kaulich S Werfel S Engelhardt MN Hirt K Yorgan T Eschenhagen L Kirchhof P Hofmann N Jaé I Wittig N Hamdani C Bischof J Krishnan RH Houtkooper S Dimmeler RA Boon 2020 Aging-regulated anti-apoptotic long non-coding RNA Sarrah augments recovery from acute myocardial infarction Nat Commun 112039 https://doi.org/10.1038/s41467-020-15995-2

65. A Vancura A Lanzós N Bosch-Guiteras MT Esteban AH Gutierrez S Haefliger R Johnson 2021 Cancer LncRNA Census 2 (CLC2): an enhanced resource reveals clinical features of cancer lncRNAs NAR Cancer 3 zcab013 https://doi.org/10.1093/narcan/zcab013

66. J Viereck A Bührke A Foinquinos S Chatterjee JA Kleeberger K Xiao H Janssen-Peters S Batkai D Ramanujam T Kraft S Cebotari F Gueler AM Beyer J Schmitz JH Bräsen JD Schmitto M Gyöngyösi A Löser MN Hirt T Eschenhagen S Engelhardt C Bär T Thum 2020 Targeting muscle-enriched long non-coding RNA H19 reverses pathological cardiac hypertrophy Eur Heart J 4134623474 https://doi.org/10.1093/eurheartj/ehaa519

67. Y Wan M Kertesz RC Spitale E Segal HY Chang 2011 Understanding the transcriptome through RNA structure Nat Rev Genet 12641655 https://doi.org/10.1038/nrg3049

68. KC Wang YW Yang B Liu A Sanyal R Corces-Zimmerman Y Chen BR Lajoie A Protacio RA Flynn RA Gupta J Wysocka M Lei J Dekker JA Helms HY Chang 2011 A long noncoding RNA maintains active chromatin to coordinate homeotic gene expression Nature 472120124 https://doi.org/10.1038/nature09819

69. M Winkle SM El-Daly M Fabbri GA Calin 2021 Noncoding RNA therapeutics - challenges and potential solutions Nat Rev Drug Discov https://doi.org/10.1038/s41573-021-00219-z

70. World Health Organization (2020) Global Health Estimates 2019: deaths by cause, age, sex, by country and by region, 2000-2019. Geneva

71. L Xiao JN Rao S Cao L Liu HK Chung Y Zhang J Zhang Y Liu M Gorospe J-Y Wang 2016 Long noncoding RNA SPRY4-IT1 regulates intestinal epithelial barrier function by modulating the expression levels of tight junction proteins MBoC 27617626 https://doi.org/10.1091/mbc.E15-10-0703

72. L Yang T Suwa WE Wright JW Shay PJ Hornsby 2001 Telomere shortening and decline in replicative potential as a function of donor age in human adrenocortical cells Mech Ageing Dev 122 16851694 https://doi.org/10.1016/S0047-6374(01)00280-9

73. M Yang Q Guo H Peng Y-Z Xiao Y Xiao Y Huang C-J Li T Su Y-L Zhang M-X Lei H-L Chen T-J Jiang X-H Luo 2019 Krüppel-like factor 3 inhibition by mutated lncRNA Reg1cp results in human high bone mass syndrome J Exp Med 21619441964 https://doi.org/10.1084/jem.20181554

74. B Yu S Wang 2018 Angio-LncRs: LncRNAs that regulate angiogenesis and vascular disease Theranostics $836543675 \mathrm{https} / / /$ doi. org/10.7150/thno.26024

75. CM Zehendner C Valasarajan A Werner J-N Boeckel FC Bischoff D John T Weirick SF Glaser O Rossbach N Jaé S Demolli F Khassafi K Yuan VA Jesus Perez de, Michalik KM, Chen W, Seeger W, Guenther A, Wasnick RM, Uchida S, Zeiher AM, Dimmeler S, Pullamsetti SS, 2020 Long noncoding RNA TYKRIL plays a role in pulmonary hypertension via the $\mathrm{p} 53$-mediated regulation of PDGFR $\beta$ Am J Respir Crit Care Med 20214451457 https:// doi.org/10.1164/rccm.201910-20410C

76. K Zhang X Han Z Zhang L Zheng Z Hu Q Yao H Cui G Shu M Si C Li Z Shi T Chen Y Han Y Chang Z Yao T Han W Hong 2017 The liver-enriched lnc-LFAR 1 promotes liver fibrosis by activating TGF $\beta$ and Notch pathways Nat Commun 8144 https://doi.org/ 10.1038/s41467-017-00204-4

77. W Zhang MJ Eckwahl KI Zhou T Pan 2019 Sensitive and quantitative probing of pseudouridine modification in mRNA and long 
noncoding RNA RNA 2512181225 https://doi.org/10.1261/rna. 072124.119

78. L Zhao J Wang Y Li T Song Y Wu S Fang D Bu H Li L Sun D Pei Y Zheng J Huang M Xu R Chen Y Zhao S He 2021 NONCODEV6: an updated database dedicated to long non-coding RNA annotation in both animals and plants Nucleic Acids Res 49 D165 D171 https://doi.org/10.1093/nar/gkaa1046

79. T Zou SK Jaladanki L Liu L Xiao HK Chung J-Y Wang Y Xu M Gorospe J-Y Wang 2016 H19 long noncoding RNA regulates intestinal epithelial barrier function via MicroRNA 675 by interacting with RNA-binding protein HuR Mol Cell Biol 361332 1341 https://doi.org/10.1128/MCB.01030-15

Publisher's note Springer Nature remains neutral with regard to jurisdictional claims in published maps and institutional affiliations. 